\title{
RESPON NYERI PADA NEONATUS PASKA PENGAMBILAN DARAH SETELAH DIBEDONG DI RUANG NEONATUS RSUD NGUDI WALUYO WLINGI
}

\author{
Tri Winarti \\ RSUD Ngudi Waluyo Wlingi \\ email: triwin@gmail.com
}

\begin{abstract}
Newborns in hospitals often have a variety of invasive procedures, so that the baby is experiencing pain. Baby's sense of discomfort and fear which will result from the pain can be observed through the tears. While wrapping the newborn to fit in a blanket (swaddling) can soothe a fussy baby or cry. The purpose of this study was to identify the effect of swaddling on pain response in neonates after venous blood sampling procedures in hospitals Ngudi Waluyo Wlingi. This study was descriptive. Samples taken by accidental sampling technique with a sample of 35 neonates. The results showed that swaddled neonates after venous blood sampling procedure was 80\% (28 respondents) pulse between 120-160 times per minute, 100\% (35 respondents) respiration between 30-60 times per minute and 51.4\% (18 respondents) $\mathrm{SaO} 2$ is greater than $92 \%$. Behavioral responses such as shrill and loud cry was $8.4 \%$ (24 respondents), stretching in some facial muscles and facial muscles stretching along each was 4.2\%(12 respondents), a strong move is 5.95\% (17 respondents ), and increased muscle tone face with flexion of the fingers and toes was 7.7\% (22 respondents). Use of swaddling post venous blood sampling procedures in neonates can be used as a way of making neonates feel comfortable and calm.
\end{abstract}

Keywords: swaddling, neonates, pain response

\begin{abstract}
Abstrak: Bayi baru lahir sering mendapatkan berbagai tindakan invasive, sehingga bayi memiliki pengalaman nyeri. Bayi merasakan ketidaknyamanan dan ketakutan akibat dari nyeri yang dapat diobserasi melalui tangisan. Tindakan pembedongan pada bayi dapat menenangkan bayi. Tujuan dari penelitian ini adalah untuk mengidentifikasi respon nyeri pada neonatus paska pengambilan darah setelah dibedong di ruang neonatus RSUD Ngudi Waluyo Wlingi. Desain dalam penelitian ini adalah deskriptif. Teknik sampling accidental, sebanyak 35 neonatus. Hasil penelitian menunjukkan 80\% (28 neonatus) heart rate 120-160 kali/menit, 100\% (35 neonatus) respirasi rate 30-60 kali/ menit dan 51,4\% (18 neonatus) $\mathrm{SaO}>>92 \%$. Respon perilaku seperti melengking dan keras menangis adalah 8,4\% (24 neonatus), peregangan di beberapa otot-otot wajah dan otot-otot wajah yang membentang di sepanjang masing-masing 4,2\% (12 neonatus), yang kuat bergerak adalah 5.95\% (17 neonatus), dan peningkatan tonus otot muka dengan fleksi jari tangan dan kaki adalah 7,7\% (22 neonatus). Penggunaan prosedur pengambilan sampel darah vena pasca dibedong pada neonatus dapat digunakan sebagai cara untuk membuat neonatus merasa nyaman dan tenang.
\end{abstract}

Kata Kunci: pembedongan, neonatus, respon nyeri

Neonatus adalah masa sejak bayi lahir hingga 28 hari, merupakan waktu berlangsungnya perubahan fisik yang dramatis pada bayi baru lahir (Bobak \& Jensen, 2005). Menurut Hamilton (2005) neonatus atau bayi baru lahir adalah dari lahir sampai usia 1 bulan periode neonatal dimana selama periode ini bayi mengalami proses kelahiran, harus menyesuaikan diri dari kehidupan intra uterin ke kehidupan extrauterin, serta mengalami pertumbuhan dan perubahan yang amat menakjubkan. Kita dapat menyimpulkan bahwa neonatus adalah masa kehidupan pertama di luar rahim sampai dengan usia 28 hari 
atau usia 1 bulan, di mana pada masa ini terjadi pematangan organ hampir pada semua sistem.

Bayi baru lahir di rumah sakit sering mengalami berbagai prosedur invasif, sebagai dampaknya bayi mengalami rasa nyeri akibat prosedur yang dilakukan. Bayi mampu mempersepsikan rasa nyeri karena jalur transmisi nyeri telah berfungsi mulai usia gestasi 20-22 minggu (Hall \& Anand, 2005). Rasa nyeri diterima sebagai bagian dari standar perawatan di rumah sakit. Rasa nyeri yang timbul, menimbulkan ketidak nyamanan pada bayi. Perilaku distres yang ditunjukkan bayi merupakan cara bayi mengkomunikasikan rasa nyeri yang dirasakannya. Rasa ketidak nyamanan bayi, rasa takut yang ditimbulkan akibat dari rasa nyeri tersebut dapat diamati melalui perilaku menangis (Hockenberry \& Wilson, 2007).

Nyeri merupakan pengalaman sensorik dan emosional yang tidak menyenangkan dan berhubungan dengan kerusakan jaringan aktual atau potensial. Nyeri merupakan suatu sensasi yang sulit untuk diingat (Bounocore \& Billieni, 2008). Namun nyeri dapat didiskripsikan berdasar kriteria yaitu stimulus yang menyebabkan rasa nyeri, perubahan fisiologis tubuh terhadap nyeri, dan perubahan perilaku. Kita bisa mengenal stimulus yang berpotensi menimbulkan rasa nyeri apabila melihar reaksi seseorang berkaitan dengan intensitas stimulus yang diberikan.

Respon fisiologis dan perilaku adalah bahwa mereka merespon terhadap nyeri dan hal ini menyebabkan distres. Perubahan fisiologis tubuh berkaitan dengan pengeluaran hormon (kortisol, endorpin, dan epineprin) serta perubahan parameter fisiologis misal denyut jantung, tekanan darah dan pengeluaran keringat. Perubahan perilaku yang berkaitan nyeri dapat dilihat dari ekspresi wajah serta respon verbal dari seseorang yang mengalami nyeri. Bayi adalah makhluk psikososial yang juga dapat merasakan kecemasan, ketakutan, dan nyeri. Rangsangan nyeri pada neonatus menghasilkan efek jangka panjang dan jangka pendek. Megel, Houser \& Gleaves (1998) menjelaskan bahwa respon nyeri terdiri dari tiga elemen yaitu perilaku yang jelas terlihat (overt behaviours), perilaku yang tersembunyi (covert behaviours) dan respon fisiologis. Perilaku yang jelas terlihat bisa diamati misalnya menangis, menyeringai, menendang, berteriak dan menarik diri. Perilaku yang tersembunyi diasosiakan dengan pikiran dan sikap terhadap pengalaman nyeri yang dirasakannya. Sedang respon fisiologis berkaitan dengan aktivasi sistem saraf simpatik di mana menyebakan pupil dilatasi, berkeringat, perubahan tanda vital seperti peningkatan denyut nadi, tekanan darah dan pernafasan. Guyton (1999) setuju bahwa perubahan fisiologis dalam tekanan darah, kecepatan pernafasan, tekanan darah, telapak tangan berkeringat diobservasi sebagai respon anak terhadap stimulus yang menyakitkan.

Bayi baru lahir telah mampu mensekresi katekolamin dan kortisol pada keadaan stres. Peningkatan kadar kortisol setelah suatu stimulus nyeri juga terlihat di saliva. Bahkan janin dalam kandungan yang mengalami prosedur invasif menunjukkan peningkatan kadar kortisol dan beta-endorfin. Perubahan fisiologi dan biokimia yang terjadi memungkinkan respon nyeri diukur secara obyektif (Corbo, 2000).

Faktor-faktor yang mempengaruhi respon nyeri pada bayi yang hospitalisasi antara lain: prosedur yang dilakukan, keterampilan operator dalam meminimalkan nyeri dan rasa tidak nyaman, usia gestasi dan posnatal, status perilaku, jumlah pengalaman nyeri sebelumnya, waktu sejak pengalaman nyeri terakhir, keparahan penyakitnya (Lissauer \& Fanaroff, 2009).

Membungkus bayi baru lahir dengan pas di dalam sebuah selimut (membedong) membuatnya lebih mudah dipegang dan sering kali menenangkan bayi yang rewel. Beberapa bayi baru lahir tampak lebih gembira bila lengan mereka berada didalam selimut (Reeder, 2012).

Rumah Sakit Ngudi Waluyo Wlingi memiliki ruangan khusus untuk merawat neonatus yang sakit yaitu ruang Edelweis. Pada bulan Juli hingga Agustus 2014 di ruang Edelweis telah dirawat 953 neonatus, $100 \%$ dilakukan prosedur invasif pengambilan darah vena. Berdasarkan uraian diatas, peneliti tertarik untuk melakukan penelitian tentang respon neonatus terhadap nyeri akibat pengambilan darah vena setelah dibedong di ruang Neonatus RSUD Ngudi Waluyo Wlingi.

Rumusan masalahnya adalah bagaimana respon neonatus terhadap nyeri akibat pengambilan darah setelah dibedong di ruang Neonatus RSUD Ngudi Waluyo Wlingi.

Tujuan dari penelitiannya adalah mengidentifikasi respon neonatus terhadap nyeri akibat pengambilan darah setelah dibedong di RSUD Ngudi Waluyo Wlingi.

Manfaat penelitian secara praktis adalah sebagai dasar untuk membuat kebijakan berkaitan implementasi konsep yang menghapuskan atau memperkecil 
distres psikologis dan fisik yang dalam perawatan neonatus (atraumatic care), khususnya saat dilakukan prosedur yang menimbulkan rasa nyeri. Manfaat secara teori adalah memperkaya bahan ajar keperawatan anak, khususnya dalam hal implementasi filosofi atraumatic care yang diberikan pada bayi.

\section{BAHAN DAN METODE}

Penelitian ini menggunakan desain deskriptif yaitu dengan mendiskripsikan atau menggambarkan fakta-fakta secara sistematis dan akurat hasil penelitian. Subyek dalam penelitian ini adalah neonatus di ruang Edelweis RSUD Ngudi Waluyo Wlingi yang dilakukan pengambilan darah sebanyak 35 neonatus. Pengambilan sampel dengan menggunakan tehnik accidental sampling. Variabelnya adalah; respon fisiologis dan respon perilaku. Pengumpulan data dengan menggunakan pengukuran; menghitung frekuensi pernafasan dengan stop wacth sedangkan frekuensi nadi dan saturasi oksigen menggunakan puls oksimetry. Untuk mengobservasi respon perilaku; tangisan, ketegangan wajah, gerakan wajah, dan tonus otot, menggunakan checklist yang berisi rentang respon dari 1 hingga 5 di masing-masing indikator respon perilaku tersebut. Analisis data dengan memberikan gambaran data respon fisiologi dengan tabel distribusi frekuensi hasil pengukuran dari masing-masing indikator respon fisiologi, sedangkan respon perilaku dianalisa dengan menghitung nilai rata-rata dari masing-masing indikator respon perilaku.

\section{HASIL PENELITIAN}

Karakteristik Neonatus di ruang Edelweis RSUD Ngudi Waluyo Wlingi tertera di tabel bawah ini:

Tabel 1. Karakteristik Responden Berdasarkan Jenis Kelamin di ruang Neonatus RSUD Ngudi Waluyo Wlingi

\begin{tabular}{llcc}
\hline No. & Jenis Kelamin & F & \% \\
\hline 1. & Laki-laki & 11 & 31 \\
2. & Perempuan & 24 & 69 \\
\hline & Jumlah & $\mathbf{3 5}$ & $\mathbf{1 0 0}$ \\
\hline
\end{tabular}

Tabel 2. Karakteristik Responden Berdasarkan Kelompok Usia di Ruang Neonatus RSUD Ngudi Waluyo Wlingi

\begin{tabular}{lccc}
\hline No. & Usia & F & \% \\
\hline 1. & $<5$ hari & 25 & 71 \\
2. & $6-10$ hari & 7 & 20 \\
3. & $11-15$ & 3 & 9 \\
\hline & Jumlah & $\mathbf{3 5}$ & $\mathbf{1 0 0}$ \\
\hline
\end{tabular}

Tabel 3. Karakteristik Responden Berdasarkan Jenis Persalinan di Ruang Neonatus RSUD Ngudi Waluyo Wlingi

\begin{tabular}{lccc}
\hline No. & Jenis Persalinan & F & \% \\
\hline 1. & SC & 21 & 60 \\
2. & Normal & 14 & 40 \\
\hline & Jumlah & $\mathbf{3 5}$ & $\mathbf{1 0 0}$ \\
\hline
\end{tabular}

Tabel 4. Respon Fisiologis Neonatus terhadap Pembedongan Paska Pengambilan Darah di Ruang Neonatus RSUD Ngudi Waluyo Wlingi

\begin{tabular}{|c|c|c|c|c|}
\hline No & Indikator & Ha sil pengukuran & $\mathbf{F}$ & $\%$ \\
\hline \multirow[t]{2}{*}{1} & Nadi & Normal (120- & 28 & 80 \\
\hline & & $\begin{array}{l}\text { Tidak normal }(<120 \\
\&>160 \mathrm{x} / \mathrm{mnt})\end{array}$ & 7 & 20 \\
\hline \multirow[t]{2}{*}{2} & Pernafasan & Normal (30 s/d 60) & 35 & 100 \\
\hline & & $\begin{array}{l}\text { Tidak Normal }(<30 \\
\&>60)\end{array}$ & - & 0 \\
\hline \multirow[t]{2}{*}{3} & $\mathrm{SaO} 2$ & $\begin{array}{l}\text { Normal }(90 \% \text { s/d } \\
100 \%)\end{array}$ & 24 & $\begin{array}{c}68 \\
5\end{array}$ \\
\hline & & $\begin{array}{l}\text { Tidak Normal }(<90 \\
\%)\end{array}$ & 9 & 1,5 \\
\hline
\end{tabular}

Tabel 5. Respon Perilaku Neonatus terhadap Pembedongan Paska Pengambilan Darah di Ruang Neonatus RSUD Ngudi Waluyo Wlingi

\begin{tabular}{llccc}
\hline No & Indikator & $\begin{array}{c}\text { Jumlah } \\
\text { Nilai }\end{array}$ & n & $\begin{array}{c}\text { Nilai } \\
\text { Rata-Rata }\end{array}$ \\
\hline 1 & Menangis & 133 & 35 & 3,8 \\
2 & Ketegangan & 104 & 35 & 2,97 \\
& wajah & & & \\
3 & Gerak fisik & 140 & 35 & 3,42 \\
4 & Tonus otot & 132 & 35 & 3,77 \\
\hline
\end{tabular}

\section{Respon Fisiologi Neonatus terhadap Nyeri} Akibat Pengambilan Darah Setelah Dibedong

Berdasarkan penelitian yang dilakukan pada tanggal 10 sampai 29 November 2014 didapatkan hasil bahwa respon fisiologi berupa nadi $80 \%$ responden adalah normal, respirasi $100 \%$ responden adalah antara 30 sampai 60 kali per menit dan saturasi oksigen $68,5 \%$ responden adalah normal. Hockenberry \& Wilson (2007) menyatakan interpretasi rasa nyeri melalui respon fisiologis diantaranya tanda vital adanya variasi peningkatan denyut jantung, respirasi cepat dan dangkal serta oksigenasi adanya penurunan saturasi $\mathrm{O}_{2}$ arteri/ $\mathrm{SaO}_{2}$. Stevens, dkk. (2009) menyatakan bahwa frekuensi denyut jantung dan saturasi oksigen merupakan indikator utama respon fisiologis terhadap nyeri pada bayi.

Didapatkan adanya saturasi oksigen normal dan tidak didapatkan adanya penurunan. Hal ini sesuai dengan pendapat Buonocore \& Bellieni (2008) yang menyatakan bahwa neonatus yang dibedong dengan 
posisi miring atau terlentang dengan lengan dan kaki fleksi secara signifikan menurunkan denyut jantung 6-10 menit setelah penusukkan, tangisan lebih pendek, waktu terbangun lebih singkat serta perubahan status tidur lebih sedikit setelah penusukkan.

Badr, dkk. (2010) menyatakan bahwa ada beberapa faktor yang mempengaruhi respon nyeri neonatus saat dilakukan penusukan, yaitu: usia gestasi, paparan nyeri sebelumnya, status terjaga status tidur dan terjaganya sebelum dilakuakn prosedur, skala kegawatan penyakit, jenis kelamin, pemakaian opioid, sedatif dan steroid. Namun membungkus bayi dengan membedong menggunakan kain katun yang lembut dapat memberikan ruang yang terbatas dan sentuhan yang terus menerus, sama seperti kondisi bayi dalam rahim dengan ruang yang terbatas. Membedong bayi dapat memusatkan perhatian bayi, menghentikan gerakan-gerakan memukul-mukul, mencegah rewel, menenangkan bayi.

\section{Respon Perilaku Neonatus terhadap Nyeri Akibat Pengambilan Darah Setelah Dibedong}

Dari hasil penelitian didapatkan respon perilaku berupa ketegangan wajah memperoleh nilai ratarata paling rendah yaitu 2,97 , nilai gerak fisik sebesar 3,42 , tonus otot sebesar 3,77 , dan tangisan sebesar 3,8 dari rentang nilai 1 sampai 5. Bayi baru lahir dapat menunjukkan nyeri secara non verbal, ekspresi wajah merupakan suatu parameter yang paling sensitif untuk menyatakan nyeri. Perubahan ekspresi wajah segera terlihat apabila sebelumnya bayi berada dalam keadaan tenang dan waspada, dan menjadi kurang jelas apabila bayi sedang tidur tenang. Ekspresi wajah yang diperlihatkan bayi yang mengalami nyeri yaitu kerutan di dahi dan diantara alis, mata terpejam rapat, lipatan nasolabial menjadi lebih dalam, bibir terbuka, mulut terbuka, mulut tertarik secara horizontal dan vertikal, lidah terjulur kaku, pipi bergetar (Marenstein, 2002).

Membungkus bayi baru lahir dengan pas di dalam sebuah selimut (membedong) membuatnya lebih mudah dipegang dan sering kali menenangkan bayi yang rewel. Beberapa bayi baru lahir tampak lebih gembira bila lengan mereka berada didalam selimut (Reeder, 2012).

Dari tabel 2 di atas didapatkan respon perilaku neonatus terhadap nyeri akibat pengambilan darah berupa respon ketegangan wajah dengan nilai ratarata paling rendah yaitu 2,97 dari rentang 1 hingga 5 dengan asumsi semakin rendah nilai berarti semakin rileks. Hal ini menunjukkan bahwa dengan membedong dapat menurunkan skala nyeri karena ekspresi wajah merupakan suatu parameter yang paling sensitif untuk menyatakan nyeri. Walaupun nilai rata-rata masih di atas setengahnya namun hal ini membuktikan bahwa membedong dapat berpengaruh terhadap respon perilaku ketegangan wajah. Adapun indikator respon perilaku yang lainnya menunjukkan nilai yang relatif tinggi, hal ini menunjukkan pembedongan pada neonatus tidak banyak mempengaruhi respon perilaku menangis, gerak fisik dan tonus otot.

Sebagaimana Reeder (2012) mengatakan bahwa membungkus bayi baru lahir dengan pas didalam sebuah selimut (membedong) membuatnya lebih mudah dipegang dan sering kali menenangkan bayi yang rewel serta beberapa bayi baru lahir tampak lebih gembira bila lengan mereka berada didalam selimut. Pembedongan termasuk juga salah satu tindakan rekondisi dalam rahim, faktor lain yang mendukung yaitu bayi dalam kondisi kenyang, sehingga mudah ditenangkan. Maka selayaknya pembedongan pada neonatus dapat dilakukan untuk menurunkan skala nyeri dan membuat bayi menjadi rileks.

\section{SIMPULAN DAN SARAN}

\section{Simpulan}

Dari hasil penelitian didapatkan sebagai berikut: Respon fisiologis neonatus terhadap nyeri akibat pengambilan darah setelah dibedong didapatkan; nadi normal sebanyak $80 \%$, pernafasan normal $100 \%$, dan saturasi oksigen normal sebanyak $68,5 \%$. Respon perilaku neonatus terhadap nyeri akibat pengambilan darah setelah dibedong didapatkan; ketegangan wajah nilai rata-rata sebesar 2,97, gerak fisik nilai rata-rata sebesar 3,42 , tonus otot nilai ratarata sebesar 3,77, dan menangis nilai rata-rata sebesar 3,8 dari rentang nilai 1 sampai 5 dengan asumsi semakin rendah nilai berarti semakin rileks.

\section{Saran}

Menjadikan tindakan pembedongan menjadi bagian dari standar prosedur operasional pengambilan darah vena pada neonates, Perawat yang bertugas diruang Edelweis diharapkan meningkatkan pengetahuan yang berkaitan dengan implementasi dan konsep perawatan neonatus dengan menghapuskan atau memperkecil distres psikologis dan fisik yang diderita oleh anak-anak dan keluarga. 
Pembekalan ilmu pada masa pendidikan akan memberikan pengaruh terhadap kualitas kinerja seseorang, karena itu hendaknya konsep atraumatic care pada perawatan neonatus dipaparkan lebih luas pada berbagai institusi pendidikan keperawatan agar para lulusan dapat menerapkan konsep ini pada pelayanan keperawatan. Penelitian selanjutnya hendaknya jumlah responden lebih banyak dengan menggunakan alat mekanik untuk menghitung respirasi serta menggunakan kelompok kontrol untuk mengetahui efektivitas pembedongan terhadap penurunan respon nyeri pada neonatus.

\section{DAFAR RUJUKAN}

Badr, L.K., Abdalah, B., Hawari, M., Sidani, S., Kassar, M., \& Nakad, P., et al. 2010. Determinans of Premature Infants Pain Responses to Heelstick. Pediatrik Nursing.
Bobak, L.M., Lowdermilk, D.L. Jensen, M.D., \& Perry, S.E. 2005. Maternity Nursing. Missouri: Mosby. Buonocore, G., \& Bellieni, C.V. 2008. Neonatal Pain: Suffering Pain and Risk and Risk of Brain Damage in the Fetus and Newborn. Italia: Springer-Verlag.

Corbo, M.G., Mansi, G., \& Stagni, A. 2000. Nonnutritive Suking During Heelstick Procedures Behavioural Distress in The Newborn Infant. Neonatology.

Gibbins, S., Stevens, B., McGrath, P.J., Yamada, J., Beyene, J., \& Breau, L., et al. 2007. A Comparison Of Pain Responses in Infant of Different Gestational Ages. Neonatology, 93(1),10-21.

Guyton. 1999. Buku Ajar: Fisiologi Kedokteran. Jakarta: EGCEdisi 9.

Hall, R.W., \& Anand, K.J.S. 2005. Phsyology of Pain and Stress in Newbonrn. Neoreviews.

Hamilton, P.M.2005. Dasar-Dasar Keperawatan Maternitas (6th Ed). Jakarta: EGC. 